\title{
On Natural Utopia Reflected in Out of Africa
}

\author{
Liu Xi, Wu Yi \\ Changchun University, Changchun, China
}

\begin{abstract}
Out of Africa by Baroness K. Blixen-Finecke wins great attention since it was published in the year of 1937. The novel presents the natural beauty of African land by unfolding the life experiences of the heroine-Karen Blixen. In this fiction, the author knits the story from multipoint views to portray a picture of natural utopia, a picturesque ideal place far from worldly disturbance. The present paper, first of all, gives a brief introduction to the story. Then, the paper mainly explores the features of natural utopia of the African land, which are reflected from three aspects: (a) Karen Blixen - a person who admires the natural beauty of the land; (b) native Africans - children who are attached to the land; and (c) Western people — arrogant invaders to the land to destroy an ideal utopian peace and harmony.
\end{abstract}

Keywords: natural utopia, admiration, African land, attachment

\section{Introduction}

Out of Africa is a memoir written by Baroness K. Blixen-Finecke, a Danish author. It was first published in 1937, which describes what happened in 17 years when Blixen made her home in Kenya which was called British East Africa later. The novel is a poetic meditation on the golden time of Blixen's life where she spent on the coffee plantation, as well as a tribute to some people who brought sweet surprises to her life there. It can be also viewed as a vivid and romantic snapshot of African colonial life in the last decades under the domination of British Empire. Blixen wrote the book in English first and then she rewrote it in Danish so that it aroused great attention to critics and readers throughout the whole world.

"A utopia is a community or society possessing highly desirable or near perfect qualities. The word was coined by Sir Thomas More in Greek for his 1516 book Utopia, describing a fictional island society in the Atlantic Ocean" (Ernst, 2000, p. 65). The term is used to "describe both intentional communities that attempt to create an ideal society, and imagined societies portrayed in fiction. It has spawned other concepts, most prominently dystopia" (Wells, 1997, p. 79).

In the novel, we can notice that the author depicted a land full of beauty of natural utopia. The story started in late 1913, when Karen Blixen, at the age of 28, went to British East Africa in order to marry her cousin, the Swedish Baron Bror von Blixen-Finecke. Then, the young Baron and Baroness established their new life in the British colony - Kenya. Very soon, the couple bought a large piece of farmland in the Ngong Hills. At first, the couple had intended to raise dairy cattle, but instead, Bror developed the farm into a coffee plantation. When the occurrence of the World War I made coffee prices rise, the Blixens began to make an investment in the business. Due to the fortune in the business, in 1917, the couple expanded their personal holdings as much as 
6,000 acres. The Blixens' marriage had a good beginning but failed to have a good ending, because in 1921, they broke up, and four years later, they divorced. Karen Blixen took over the management of the farm on her own. Karen Blixen, greatly independent and capable, adapted herself to both the farmland management and business work very well. She devoted all her love to the land and never looked down upon the native workers. However, unfortunately, the farm deeply got involved into debt, so that she had to sell it finally in 1931. Then, she returned to her motherland, Denmark.

This paper aims to discuss the features of natural utopia reflected in the novel from three perspectives: (a) Karen Blixen - a person who admires the natural beauty of the land; (b) native Africans - children brought up on the land; and (c) Western people - arrogant invaders to the land after they discovered the natural beauty of it.

\section{Admiration to the Natural Land Reflected by Karen Blixen}

In Out of Africa, Blixen helped to "unfold a gorgeous picture which exhibited an idealistic natural utopia like Garden of Eden for modern people" (Lyman, 2003, p. 105). When first settling down on African highland, Blixen was greatly shocked by its vast territory and incomparable nobility. With its unique features, the high geographical position made the highland a refined continent, which assured people to feel like they were living up in the open air. Blixen gave a comprehensive description to the place with vivid words and looked on it as a locality for people to live poetically:

I had a farm in Africa, at the foot of Ngong Hills. The equator runs across these highland... In the daytime, you felt that you had got high up, near to the sun, but the early mornings and evenings were restful, and the nights were cold. (Blixen, 2001, p. 15)

From the perspective of Blixen, the sky in Africa was full of powerful, weightless, and changing clouds filled up with blue energy. Moreover, the whole highland was full of transparent and clear atmosphere just like that of an exquisite pottery. What made the author astonished was that at that time, Africa still preserved the original beauty and natural attraction. For example, the highland was smothered with massive and dense lilies, long wild grass, and towering trees sending forth fragrance of fresh earth and romance, misty hills were changing their characters frequently within a day, and the mountains in distance were keeping noble tops standing unshakably.

The relationship between African land and all organic livings was interdependent, because for a variety of animals, the land acted as their motherland. At sunrise, big elands were rambling in a long row to watch the land quietly and peacefully. The haughty camels like cactus could be viewed as the products of the droughty desert beyond all earthly sufferings. The arrogant giraffes wearing an air of grace looked like speckled wild flowers advancing forwards and backwards slowly.

In Out of Africa, Blixen gave a description to both picturesque scenery and a variety of leisurely animals with unique features. Blixen and animals were connected by love rather than friendship, because in Africa, Blixen was the neighbor of her beloved animals and was capable of thinking and feeling the same way as they did. Blixen admired animals for their heroic struggle against any awful condition and she actually lived in the animal world that she always favored, "You are me, and I am you" (Blixen, 2001, p. 152). As a human being, Blixen shared the same carefree delight and leisurely happiness with animals. She could feel the mad pleasantness of the horses the moment they stepped on the plains covered with dense and fresh grass. She came 
very close to the elands to appreciate their elegance and beauty. She also admired the stillness of wild animals and believed that people in industrialized society had lost their aptitude of stillness and should learn from the wild animals and even reflect in silence from them. Apart from the admiration and love to the wild animals, Blixen had abandoned all shooting expeditions for years ever since she came to Africa. Lulu was a lost antelope adopted by Blixen. With charming grace and surprising beauty, Lulu quickly acquired a commanding position in Blixen's home like a real princess. Finally, Lulu went back to the woods so as to establish her own family when she became an adult antelope. Although she left, Lulu often came back to her old home and visited those old acquaintances just like a married daughter paid a visit to her mother. The absolute connection between Lulu and the house seemed unusual and honorable, which created unexpected attraction for the house. What is more, the trust between Lulu and people was a strong evidence to support the mutual dependence between man and animals. The connection between Lulu's family and the house was so close that the intimacy lasted for many years, which attributed to the happiest moment in Blixen's life living in Africa. Blixen viewed the intimate relation as a token of friendship from Africa. After she left Africa, the bell on Lulu's neck usually sang clearly in her dream like a song of Africa haunting in the memory.

On the African land, there lived a community like a natural utopian society. Everything lived in harmony with each other and followed the rhythm of nature. Africans had a leisure rhyme of life, following the nature rules. Nature, including the land, animals, and man, was a harmonious community, which was a part of paradise on earth. The beauty, peace, and melody caught the eyes of Blixen and even tempted her foot. Each morning when she woke up, she felt that she was just in the place where she ought to be.

\section{Attachment to the Natural Land Reflected by the Native Africans}

In the eyes of Blixen, the land in African was her home which comforted her traveling heart. While as for Africans, the land was more than a simple home but a precious life. Not only did they love the land, but also they worshiped it with faithful heart, no matter what the land could offer them-happiness or disasters. The African natives and the land were in a mutually beneficial relationship. The natives followed the tempo of the land and integrated with the nature in harmony. Even when building the houses, they observed the wildness and irregularity of the land, compromised to cater to the complete indifference to the surroundings of their homes, and never had an idea to make a change or control it according to their personal wills. They were not the monarch of the land but a regular resident on it. In so many years, the African land bestowed the natives so much that people there harvested various cereals from it. There people could see a natural and idyllic picture of life: the maize and speckled pumpkins were growing vigorously, and cloud-like goats were grazing on the pasture, and chickens and kids were chasing happily. Finally, troublesome times came, when there were years of drought, threat of lions, leopards, and such beasts to children, and the swarms of grasshoppers were leaving the leafless grass, the land was against people. However, they took all these disasters with humility and resignation, hoping that the motherland would grant them a few hours of unbelievable happiness next time when grasshoppers passed across the cornfield and failed to settle or when spring came, the rain fell early and plentifully to make all those fields and plains blossom out and gave rich harvest.

The harmonious connection between the natives and the land was also reflected in the fact that the land had accepted people living on it, for:

The natives were Africa in flesh and blood. The tall extinct volcano of Longonot that rises above the Rift Valley, the broad Mimosa trees along the rivers, the elephant and the giraffe are not more truly Africa than the natives were, small 
figures in an immense scenery. (Blixen, 2001, p. 20)

On the land's immense scenery, the natives were small and humankind's existence to the land was the different notes of a song, though variations were still about the same theme. Moreover, when people were dead, they were not to be buried but be left on the ground and laid out to the sun and stars, so the dead body could be picked and cleansed openly, promptly, and neatly by wild animals in order to make one integrate with nature and be a component of the land.

To sum up, as for both Blixen and the natives, the land was their root and they needed it to keep a peaceful life. Human was just a part of the land for its steadiness and nobility. People loved the land with eagerness and lived with endless hope. Blixen could not help her love to the land and recorded the grass, the air, and even the disasters and invisible mountains with hearty worship. The Africans were always in accordance with the land. Human beings were in real harmony with the nature.

\section{Arrogance to the Natural Land Reflected by Western People}

In Out of Africa, as a whole, both "Blixen and Africans lived in harmony with the land which sent off the air of natural utopia" (Lyman, 2003, p. 55). Their love and worship for the land and the equality they endowed with animals were the most prominent features in the relationship between human and nature. However, the so-called civilized Westerners in Africa made contrasts greatly with that of Blixen and Africans. The beginning point of the "civilized" Westerners completely based on the principle of man-centered theory. In order to have what they desired, they strived to change nature. The Westerners' isolation with nature was largely reflected in their abuse of the land cruelty as well as indifference to animals.

In the Africans' eye, nature was the root of their lives. Only following the rhyme of the nature did they each live a pleasant life, which produced their worship of the land. However, to the civilized Westerners, the land was a belonging to them, so they could develop and use resources at will. What is more, they completely ignored the harmony between man and the land and took advantage of it. As what Said (1994) stated in his Culture and Imperialism, "Wherever Europeans go, they would immediately change the local shelter. Many plants, animals, crops and new forms of construction bring lots of changes including new pollutants and diseases, ecological imbalances and indigenous displacement" (p. 102). There was no exception for Westerners in Africa. They built churches, factories, and government buildings at their will, attempting to maximize their benefits by changing the appearance of the land and trying to build Africa into big cities like those of Europe. The buildings they built were always splendid and impressive in the landscape, making people feel that they should live in somewhere of Europe. Facing the wilderness and irregularity of African highlands, they yearned keenly for geometrical figures with blind greed. There was no doubt that Westerners in their boots and constant hurry clashed against the landscape.

The Africans treated the animals living on the highlands as their beloved children. But in the eyes of Westerners, animals were commodities which could bring them money and interest. People caught animals, even endangered animals, to make experiments or trade them to dealers. Endless greed of money drove them to hunt animals constantly and in large scale. Lovely flamingos and giraffes both had a fate of tragedy and became means of Westerners to chase benefits and profits. Blixen, with great sorrow, described the heartbreaking facts and tries in her own way to give love and tender care to the animals and called on people to befriend animals. 
To protect animals, it was not just to keep one or two animals alive, the meaning of animal protection was that human began to consider about life with equality. Animals were human's companions and family numbers. To us, protecting animals could conserve biological diversity, increase human happiness, and could make human learn how to respect life. Research showed that people who kept pets were with longer longevity. They were more caring about animals' life. People would feel relaxed when they were giving love and helping. We needed to keep the harmonious coexistence of man and nature. Protecting animals could made human learn how to respect for life.

Greed of fortune led Westerners to abuse the land and maltreat living things there. They had no such thing as peaceful mind, they stood against nature and could only bring cruelty and indifference to the locality. Their cruel behavior were based on human-centered theory, which advocated that all things in nature belonged to human and could be explored and changed as long as there were profits to make human materially content.

\section{Conclusion}

The novel, Out of Africa, is full of the atmosphere of natural utopia which depicts an ideal life without social disturbance. The native Africans follow the natural rules and accept what the nature brings to

them-harmony or disasters, building an interdependent relation between the land and Africans. The equality and intimacy between man and nature are symbols of natural utopia. In the eye of Blixen, local people are real practitioners of ecological holism and natural utopia is the foundation of spiritual utopia. Affected by Africans' peaceful inner world, Blixen keeps on seeking for her self-identity and tries to internalize an integral self. Blixen regards Africa as heaven on earth. However, Western settlers who have lost the sense of belonging and the faith in God, flood into the divine land and spoil it at will, which is the reason causing the crisis of natural and social ecology. The novel represents the feature of natural utopia by three typical aspects: (a) Karen Blixen - a person who loves the natural harmony of the land; (b) native Africans - children who were brought up by the land so that they hold deep affections to the land; and (c) The Western people-invaders to the land since they considered the land as a natural utopian place.

\section{References}

Blixen, K. (2001). Out of Africa. Eastbourne, U.K.: Gardners Books Ltd.. Ernst, B. (2000). The spirit of utopia. Redwood, C.A.: Stanford University Press.

Frank, M. (1979). Utopian thought in the Western world. Oxford, U.K.: Blackwell Publishers Ltd..

Gui, Y. Q. (1985). Selected reading in English and American literature. Beijing: Translation Company Press.

Kumar, K. (1987). Utopia and anti-utopia in modern times. Oxford, U.K.: Blackwell Publishers Ltd..

Kumar, K. (1991). Utopianism. Buckingham, Bucks: Open University Press.

Lyman, T. (2003). Thinking utopia: Steps into other worlds. New York, N.Y.: Berghahn Books.

Said, E. W. (1994). Culture and imperialism. New York, N.Y.: Vintage Books (Random House).

Wells, H. G. (1997). A modern utopia. Lincoln, N.E.: University of Nebraska Press.

Yu, W. X. (2002). Cultural study: An introduction. Beijing: People's Press. 